\title{
Pemberdayaan Ekonomi Masyarakat Melalui Pengolahan Hasil Bumi Lokal Berbasis Pemasaran
}

\author{
Tegar Noviara Abie ${ }^{1}$, Cantika Sari Siregar ${ }^{2}$ \\ Universitas Negeri Surabaya, JL. Lidah Wetan, Lidah Wetan, Kec. Lakarsantri, Kota \\ Surabaya, Jawa Timur 60213 \\ Email: tegar.17080694021@mhs.unesa.ac.id
}

\begin{abstract}
ABSTRAK
Dusun Kulubanyu memiliki hasil bumi yang melimpah namun warganya kurang memiliki pengetahuan untuk mengolah kembali menjadi produk yang dapat menambah nilai jual. Tujuan dari pengabdian masyarakat ini adalah memberikan pemahaman terkait nilai tambah hasil bumi berupa pisang yang diolah menjadi kripik oleh ibu-ibu rumah tangga di Dusun Kulubanyu Desa Tawangrejo. Terdapat beberapa tahapan metode pelaksanaan yang dilakukan yaitu memberikan penyuluhan terkait industri rumah tangga, memberikan materi pemasaran menggunakan media sosial instagram, dan memberikan pembelajaran cara menetapkan harga jual. Hasil menunjukan bahwa adanya peningkatan pemahaman Warga Dusun Kulubanyu Desa Jatirejo terkait pentingnya pengolahan hasil bumi sebelum produk dijual agar mendapatkan keuntungan yang lebih tinggi, warga telah mampu mengoperasikan media sosial instagram untuk pemasaran, warga dapat menghitung penetapan harga jual secara sederhana, dan dapat memperluas pemasaran melalui penempatan produk ke tempat wisata sekitar agar produk lebih cepat dikenal.
\end{abstract}

Kata kunci: Ekonomi Desa; Kripik Pisang Aneka Rasa; Pemasaran; Harga Jual; Dusun Kulubanyu

\begin{abstract}
Kulubanyu Hamlet has abundant agricultural products, but its residents do not have the knowledge to reprocess them into products that can add to the sale value. The aim of this community service is to provide an understanding of the added value of agricultural products in the form of bananas which are processed into chips by housewives in Kulubanyu Hamlet Tawangrejo Village. There are several stages of the implementation method carried out, namely providing counseling related to the home industry, providing marketing materials using social media Instagram, and providing learning how to set selling prices. The results show that there is an increase in the understanding of the residents of Kulubanyu Hamlet Jatirejo Village regarding the importance of processing agricultural products before the product is sold in order to get higher profits, residents have been able to operate social media Instagram for marketing, residents can calculate simple selling price, and can expand marketing through placement of products to nearby tourist attractions so that the product is recognized more quickly.
\end{abstract}

Keywords: Village Economy; Various Banana Chips; Marketing; Selling Price; Dusun Kulubanyu

\section{PENDAHULUAN}

Secara garis besar semua kegiatan pengembangan masyarakat dilakukan dengan tujuan utama yaitu membentuk struktur masyarakat yang meningkatkan semangat swadaya dan partisipasi masing-masing individu. Pengembangan masyarakat yaitu memperkukuh interaksi sosial dalam masyarakat, terciptanya semangat kebersamaan antar individu, 
munculnya rasa solidaritas yang diwujudkan dengan cara berkomunikasi dengan pihak lain secara alamiah tanpa intervensi dalam hal apapun, didasari penuh pemahaman dan kemudian dilakukan dengan aksi sosial nyata (Zubaedi, 2013).

UU No. 6/2014 tentang Desa menjadi prioritas penting bagi pemerintah karena Desa sebagai "kekuatan besar" yang nantinya memberikan kontribusi terhadap salah satu misi Indonesia yang berdaulat, sejahtera, dan bermartabat. Pemerintah juga melakukan pengawasan yang intens terhadap implementasi UU Desa dilakukan secara sistematis, konsisten dan berkelanjutan, agar terwujudnya suatu desa yang maju, kuat, mandiri, dan demokratis. Dengan adanya implementasi tersebut diharapkan masyarakat di Desa akan mendapatkan kesejateraan hidup yang layak dan setara dengan masyarakat lainnya. Kesejahteraan hidup sendiri merupakan tujuan dari setiap individu, salah satu indicator yang menyebabkan tidak berhasilnya masyarakat untuk sejahtera yaitu dikarenakan kemiskinan. Oleh karena itu kemiskinan harus diatasi karena menggambarkan suatu bentuk ketidak sejahteraan dalam pemenuhan kebutuhan ekonomi (Yasin, dkk., 2015).

Dusun Kulubanyu termasuk dalam wilayah Desa Tawangrejo, Kecamatan Jatirejo, Kabupaten Mojokerto yang memiliki banyak potensi hasil perkebunan hasil alam. Sehingga hasil perkebunan yang dimiliki dusun tersebut sangat melimpah, karena letaknya yang strategis dideretan pegunungan sehingga cocok untuk dijadikan lahan perkebunan. Salah satu hasil perkebunan yang cukup baik dipanen dalam Dusun tersebut yaitu pisang. Namun sayangnya pisang yang telah dipanen langsung dijual kepada tengkulak tanpa adanya proses pengolahan terlebih dahulu sehingga membuat harga jual pisang tersebut masih rendah, ditambah lagi pisang yang telah dipanen tidak mampu bertahan lama sehingga pisang yang tidak laku terjual menjadi busuk dan dibuang. Selain itu kegiatan sehari-hari yang dilakukan oleh warga Kulubanyu juga kurang produktif karena hanya bekerja di pabrik, sawah, dan kebun. Ditambah lagi rasa kekeluargaan antar warga desa yang kurang mengakibatkan adanya sifat indivualis dan rasa kurang perduli antar warganya.

Mindset yang ditanamkan dalam Dusun Kulubanyu adalah tingkat kesuksesan individu diukur dari status pekerjaan mereka yang telah berhasil bekerja menjadi pegawai kantor atau kayawan perusahaan ternama. Hal tersebut dikarenakan kurangnya edukasi dan pendidikan warga Dusun tersebut untuk memanfaatkan peluang bisnis dan kurangnya membuka pikiran yang luas untuk menciptakan lapangan kerja yang baru sehingga dapat menekan tingkat pengangguran khususnya di Dusun Kulubanyu itu sendiri. Sistem pemasaran produk juga menjadi kendala yang dialami oleh warga Dusun Kulubanyu. Berdasarkan survei yang dilakukan oleh peneliti kepada Seperangkat Desa (Sekertaris Desa) 
Tawangrejo, bahwasannya warga di Dusun Kulubanyu kurang mampu dalam memasarkan produk yang telah dibuat, sehingga membuat mereka mengurungkan niat untuk menciptakan suatu hasil olahan yang nantinya akan dijual lagi. Karena menurut mereka lebih baik menjual kepada tengkulak dan pasar yang dapat dengan mudah dijual dari pada harus melakukan pengolahan yang membutuhkan tenaga, ditambah lagi minimnya pengetahuan terkait pemasaran produk. Selain itu masyarakat di Dusun Kulubanyu masih belum faham terkait penentuan harga yang sesuai dengan peroses pengolahan produk yang dikerjakan. Karena selama ini masyarakat menentukan penjualan pisang dengan melihat harga pasar yang sedang berlaku. Sehingga perlu pemahaman bagi warga Dusun Kulubanyu terkait penentuan harga jual yang merupakan jumlah moneter yang dibebankan oleh unit yang dimiliki oleh penjual yang nantinya akan dibebankan kepada pembeli atas barang yang diserahkan (Mulyadi, 2012). Penentuan harga jual dapat dikatakan penting karena merupakan salah satu komponen pokok aturan ketertiban suatu bisnis yang jika tidak diterapkan akan menyebabkan usaha kecil tidak dapat memahami terkait penentuan biaya dan aliran kas dengan baik (Herawati dkk., 2020).

Pengabdian ini memfokuskan pada pemberdayaan masyarakat Dusun Kulubanyu dalam mengolah hasil bumi berupa pisang menjadi kripik pisang yang memiliki berbagai varian rasa. Kegiatan pengolahan hasil bumi tersebut dilakukan karena warga Dusun Kulubanyu hanya langsung menjual hasil panen pisang tersebut tanpa ada proses pengolahan terlebih dahulu sehingga nilai jualnya rendah dan kurangnya pengetahuan terkait pemasaran membuat mereka kurang inovatif dalam melakukan kegiatan ekonomi serta ketidaktahuan terkait penentuan harga jual dan sistematika penjualan produk yang benar masih belum diterapkan. Oleh karena itu perlunya pendampingan secara berkala kepada warga di Dusun Kulubanyu untuk dapat mengolah hasil bumi dan memahami terkait pemasaran produk agar dapat meningkatkan potensi ekonominya dan memahami terkait sistem keuangan mengenai penentuan harga jual.

\section{METODE}

Kegiatan pengabdian dilaksanakan di Dusun Kulubanyu, Desa Tawangrejo, Kecamatan Jatirejo, Kabupaten Mojokerto Jawa Timur. Kegiatan tersebut dilakukan selama selama 6 bulan mulai dari tanggal 1 Juni 2019 sampai dengan 19 November 2019. Metode yang dilaksanakan yaitu dengan membuat timeline kegiatan secara berkala, yaitu: Menjalin kemitraan dengan seperangkat Desa, mengadakan sosialisasi Home Industry, dan memberikan pembelajaran terkait pemasaran produk melalui media online Instagram. Selain 
itu juga memberikan informasi terkait pengelolaan keuangan untuk proses produksi produk. Kelompok masyarakat yang menjadi sasaran dalam kegiatan ini yaitu Ibu-Ibu dan masyarakat yang berada di wilayah Kulubanyu.

\section{HASIL, PEMBAHASAN, DAN DAMPAK}

Kegiatan pengabdian yang dilakukan di Dusun Kulubanyu dipilih berdasarkan lokasi karena daerah ini berada pada tempat penghasil hasil bumi berupa pisang yang melimpah dan mendapatkan respon yang baik dari masyarakat, semua program yang telah disusun dapat terealisasi dengan baik. Sebelum melakukan kegiatan terlebih dahulu tim pengabdian mendatangi kediaman seperangkat desa untuk meminta izin atas kegiatan pengabdian yang dilakukan secara berkala oleh tim pengabdian selama enam bulan. Seperangkat Desa yang didatangi oleh tim yaitu Bapak Dameri selaku kepala Desa, Bapak Sutarji selaku Sekertaris Desa, dan Bapak Parmono selaku Kepala Dusun Kulubanyu. Selain untuk meminta izin, tim juga berkomunikasi mengenai karakteristik masyarakat yang tinggal di Dusun Kulubanyu dan juga warga yang dapat menjadi penggerak warga lainnya dalam mengikuti kegiatan yang telah dirancang oleh tim. Proses tersebut membutuhkan waktu satu bulan sampai dengan proses administrasi perizinan melalui tim pengabdian dan pihak Dusun Kulubanyu telah selesai.

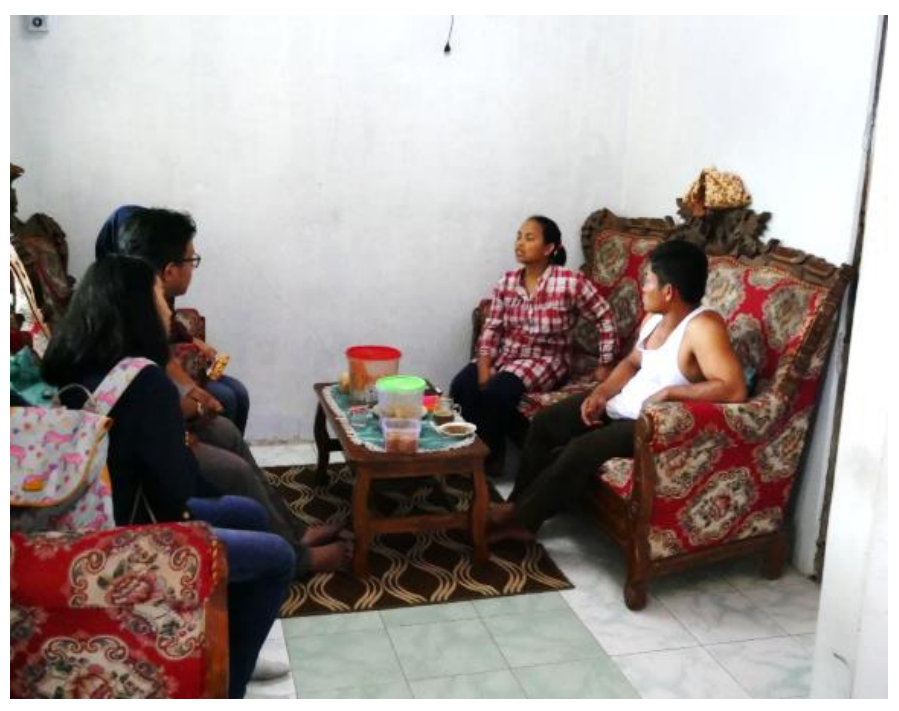

Gambar 1. Proses Perizinan Kepada Sekertaris Desa

Kemudian pada bulan kedua tim mengundang warga Dusun Kulubanyu khususnya ibu-ibu untuk menghadiri kegiatan penyuluhan mengenai home industry yang akan disampaikan oleh Pemateri Dosen Kewirausahaan Jurusan Akuntansi Universitas Negeri Surabaya, kegiatan penyuluhan ini diawali oleh pembukaan yang dilakukan oleh Bapak 
Dameri selaku kepala Desa Tawangrejo. Adapun materi yang dibahas dalam penyuluhan yang dilakukan yaitu bagaimana menjadi ibu rumah tangga yang produktif, manfaat menjadi wirausaha, tips mengelola home industri dengan baik, dan mengedukasi mengenai pemasaran sesuai perkembangan zaman. Kegiatan penyuluhan diikuti oleh 25 ibu-ibu yang telah diinformasikan sebelumnya melalui surat undangan sebanyak 34 yang telah disebar. Kegiatan penyuluhan ini merupakan indikasi pertama yang menunjukkan bahwa antusias ibu-ibu Dusun Kulubanyu untuk mendapatkan edukasi cukup tinggi. Pada akhir acara tim melakukan diskusi kepada ibu-ibu yang hadir bahwa kedepannya akan dibentuk 4 kelompok produksi yang masing-masing kelompok akan memproduksi kripik dalam rumah produksi yang nantinya akan ditentukan setelah proses pelatihan pembuatan produk selesai

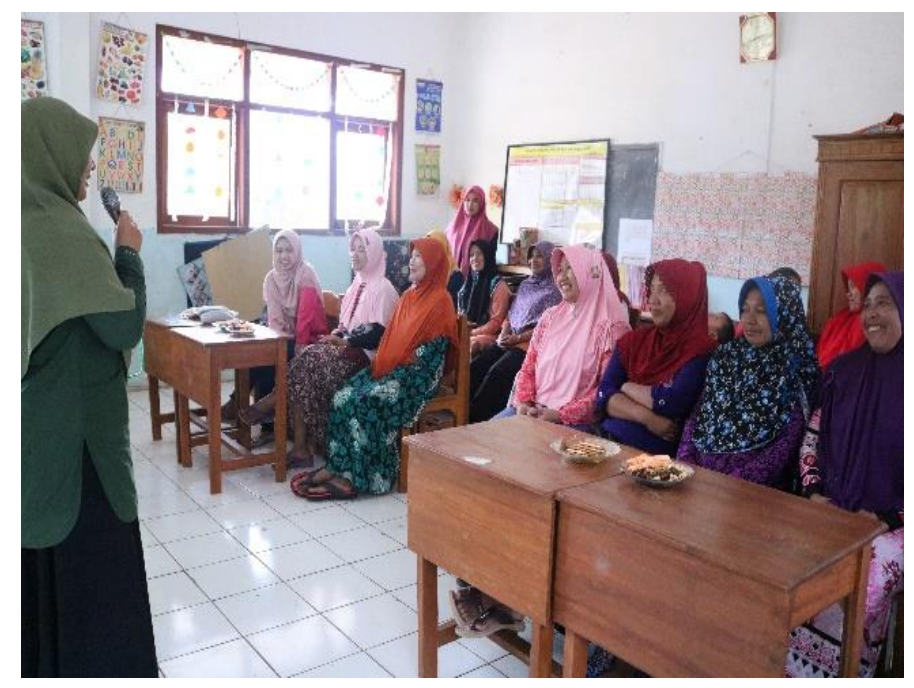

Gambar 2. Kegiatan Penyuluhan "Home Industry"

Setelah dilakukan penyuluhan terkait dengan "Home Industry" tim pengabdian memberikan edukasi terkait dengan pemasaran melalui media online. Hal ini dilakukan oleh tim karena pemasaran digital dirasa lebih akuntanbel dan lebih efektif dibandingkan dengan pemasaran tradisional yang lebih memperkarsai interaksi dengan pelanggan (Kotler dkk., 2019; Sigalingging, 2020). Dan selaras dengan pendapat (Rahayu \& Laela, 2018) dimana pada abad ini yang dikenal dengan revolusi industri 4.0 mengenai siapa yang menguasai informasi, maka akan menguasai dunia, serta informasi yang semakin meningkat didukung dengan alat informasi yang semakin canggih yaitu smartphone. Salah satu media yang digunakan oleh tim yaitu Instagram karena Instagram merupakan aplikasi yang mudah digunakan, mudah diakses, dan penggunanya berbagai macam kriteria. Sehingga pemasaran yang dilakukan dengan menggunakan Instagram lebih mudah dan dapat dengan cepat dikenal oleh masyarakat luas. Poin penting yang disampaikan kepada warga Kulubanyu yaitu tata cara menata feed Instagram agar terlihat lebih menarik, tips dan trik 
mengoperasikan postingan dalam Instagram terkait waktu yang cocok untuk memposting dan memanfaatkan fitur Instagram berupa story dan Instagram ads sebagai Langkah untuk promosi produk.
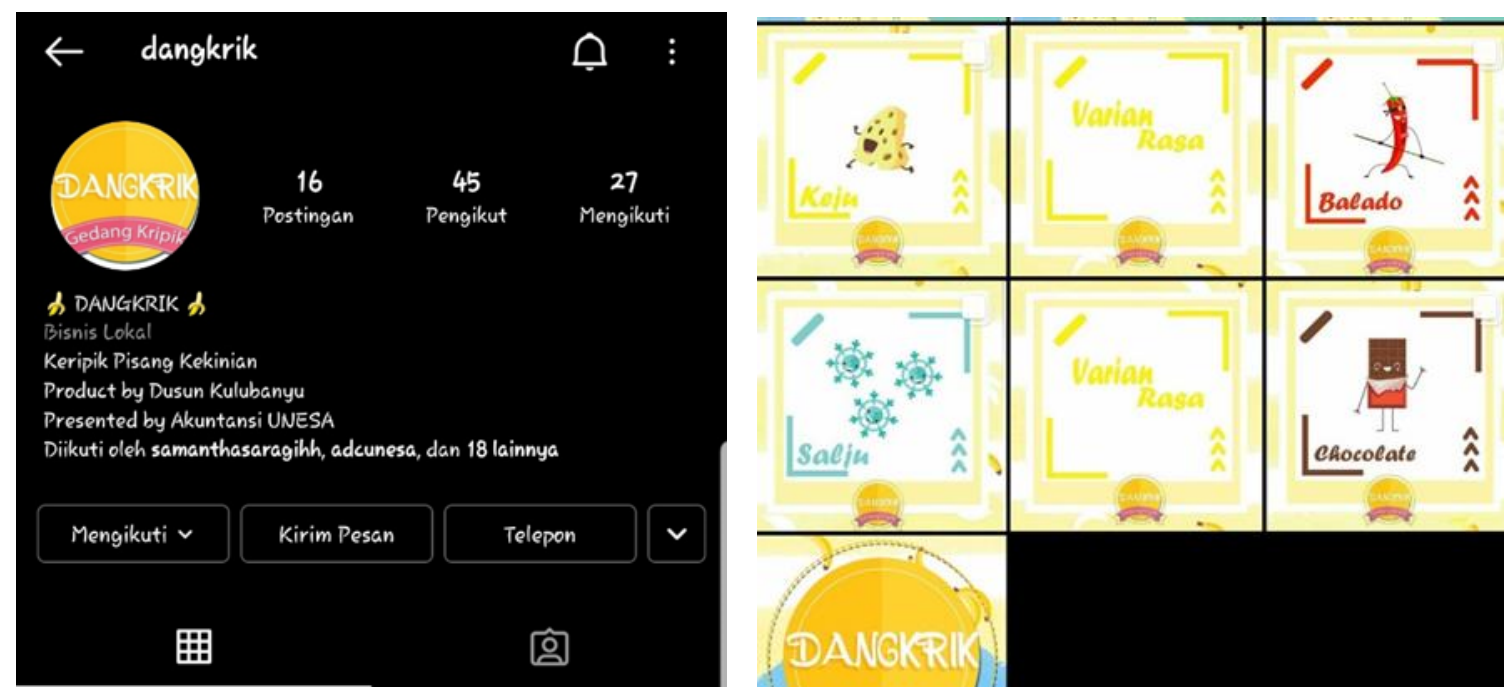

Gambar 3. Tampilan Feed Instagram Produk Kripik Dusun Kulubanyu

Pada bulan kedua tanggal 25 Juli 2019 tim pengabdian memberikan pelatihan pembuatan kripik pisang aneka rasa ke-1 beserta pembelian peralatan dan perlengkapan yang dibutuhkan seperi wajan besar, mesin sealer, alat pemasrah, kompor, dan yang dihadiri oleh 16 peserta. Kemudian pelatihan ke-2 yang dilakukan pada tanggal 3 Agustus 2019 dihadiri oleh 20 ibu-ibu warga Dusun Kulubanyu. Setelah pelatihan dilakukan dibentuk sebuah tim produksi yang terdiri dari 5 anggota dalam setiap tim untuk memproduksi pisang kripik aneka rasa sesuai dengan jumlah yang ditentukan nantinya. Setelah penentuan tim produksi beserta rumah produksi, tim pengabdian melakukan diskusi dengan warga kulubanyu terkait dengan kuantitas yang akan diprodusi periode pertama. Dalam diskusi pertama tim pengabdian mengajarkan cara menghitung penentuan harga jual secara sederhana agar warga dusun setidaknya mengerti bagaimana cara menghitung harga jual produk sesuai dengan keuntungan yang diinginkan. Perhitungan harga jual sendiri yaitu dengan menjumlah seluruh biaya-biaya yang dikeluarkan untuk produksi ditambah dengan beban-beban lainnya serta menjumlahkan dengan presentase laba yang diinginnya kemudian membagi dengan kuantitas produk yang dihasilkan.

Kegiatan produksi kripik pisang aneka rasa dilakukan sebanyak tiga kali yaitu pada tanggal 16, 23, dan 1 September 2019. Penentuan tanggal produksi disesuaikan dengan ketersediaan produk, apabila produk yag dipasarkan sudah outstock maka diproduksi ulang. 
Adapun hasil rekapitulasi laporan penjualan Kripik Pisang aneka rasa produksi hasil bumi Dusun Kulubanyu pada tabel 1.

Tabel 1. Laporan Hasil Produksi dan Penetapan Harga Kripik Pisang Aneka Rasa

\begin{tabular}{|c|c|c|c|}
\hline Keterangan & Produksi ke-1 & Produksi ke-2 & Produksi ke-3 \\
\hline $\begin{array}{c}\text { Harga Pokok } \\
\text { Penjualan }\end{array}$ & Rp 942,500.00 & Rp 1.360.000,00 & Rp 1.450.000 \\
\hline $\begin{array}{l}\text { Presentase } \\
\text { keuntungan } \\
\quad(75 \%)\end{array}$ & Rp 1.649.375,00 & Rp 2.380.000,00 & $\operatorname{Rp} 2.537 .500$ \\
\hline Kuantitas & 300 & 350 & 400 \\
\hline Harga & Rp 5.497,00 & $\operatorname{Rp} 6.800,00$ & $\operatorname{Rp} 6.300,00$ \\
\hline Jual/Produk & $(\operatorname{Rp} 5.500,00)$ & $(\operatorname{Rp} 7.000,00)$ & $(\operatorname{Rp} 6.500,00)$ \\
\hline
\end{tabular}

Sumber 1 : Data diolah 2020

Untuk presentase $75 \%$ ditentukan dari kesepakatan antara Dusun Kulubanyu dengan tim pengabdian sehingga dapat diperoleh harga jual yang dihitung berdasarkan perhitungan presentase keuntungan. Harga yang diperoleh berbeda disetiap produksinya karena disesuaikan dengan harga pisang yang naik dipasaran dan cost yang dikeluarkan ketika menambah varian rasa.

Tim pengabdian juga membantu pemasaran produk kripik pisang yang sebelumnya telah didiskusikan yaitu melalui Instagram, kami menambahkan beberapa konten berupa feed yang memiliki warna dasar kuning karena sesuai dengan warna identik pisang serta menambahkan postingan berupa pembelian yang dilakukan oleh konsumen agara menunjukkan bahwa produk kripik pisang aneka rasa juga banyak diminati oleh masyarakat pada umumnya. Kemudian di Dusun Kulubanyu sendiri masih banyak masyarakat yang tidak menggunakan Instagram sebagai alat komunikasi atau sosial media, sehingga langkah yang dilakukan oleh tim pengabdian yaitu mendisitribusikan produk disekitaran desa melaluimtoko-toko kelontong dan juga menintipkan produk di tempat-tempat wisata sekitaran desa yaitu di Wisata Religi Makam Islam Troloyo dan Candi Tikus Mojokerto karena menurut tim para wisatawan akan membeli produk khas daerah yang didatangi, sehingga cocok sebagai langkah awal untuk memperkenalkan produk asli Kulubanyu. Selain itu tim juga memperhatikan bentuk kemasan yang menarik agar ketika konsumen meihat produk tertarik untuk membeli. Kemasan produk keripik pisang menggunakan plastik kemasan standing yang dapat dibuka tutup sehingga lebih ekonomis dan praktis serta untuk detail kemasan menggunakan stiker yang dicetak dengan kertas art paper dan disesuaikan dengan ukuran plastik standing. 


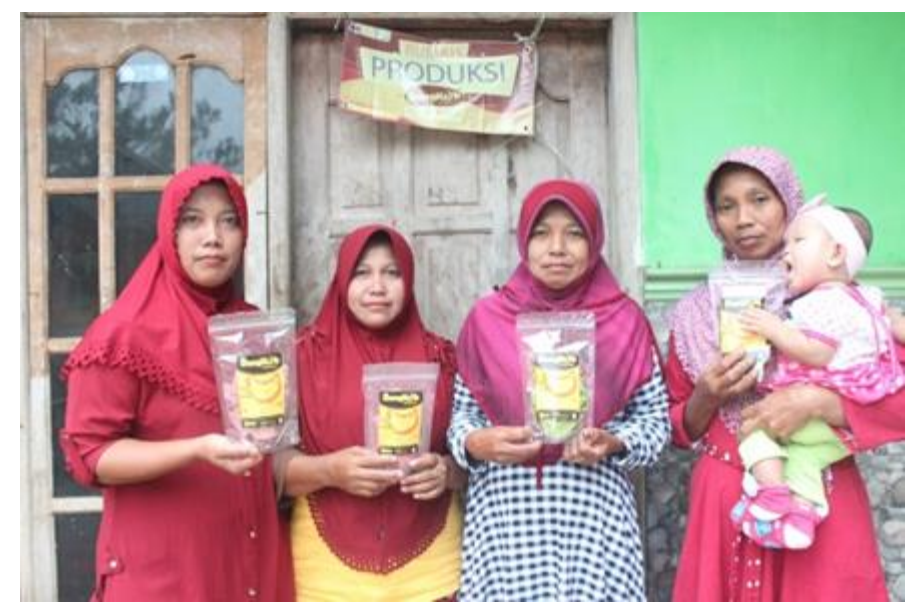

Gambar 4. Hasil Produk Siap Jual Bersama Tim Produksi

Adanya kegiatan pengabdian yang dilakukan oleh tim pengabdian membuat warga Dusun kulubanyu memiliki inisiatif untuk mengubah pola pemasaran hasil bumi lokal dengan cara mengolah terlebih dahulu agar memiliki nilai jual yang tinggi. Kemudian untuk proses penetapan harga jual, warga yang biasanya menggunakan harga pasar namun telah menggunakan perhitungan harga dengan memperhatikan harga pokok penjualan serta menentukan presentase keuntungan agar mendapatkan profit yang diinginkan. Pemasaran yang sebelumnya dilakukan dengan cara memanfaatkan tengkulak dan berjualan di pasar kini mulai perlahan memanfaatkan revolusi industri 4.0 dengan menggunakan aplikasi sosial media berupa Instagram untuk proses kegiatan jual beli produk.

\section{SIMPULAN}

Kegiatan pengabdian tentang pengenalan tata cara pemanfaatan produk lokal, pemasaran produk, dan perhitungan harga jual produk di Dusun Kulubanyu Desa Tawangrejo Kecamatan Jatirejo Kabupaten Mojokerto memberikan hasil yang baik yaitu tim produksi semakin bertambah dan produk yang dihasilkan setiap produksi meningkat. Selain itu pemahaman warga terkait dengan pemasaran juga meningkat dengan setiap kali produksi, produk yang dititipkan toko sekitar Dusun selalu sold out. Program ini juga berhasil memberikan pemahaman warga bagaimana cara menentukan harga jual sesuai dengan keinginan yang didapatkan. Kegiatan pengabdian ini masih sangat diharapkan oleh tim agar dapat meningkatkan pengetahuan terkait ilmu perhitungan akuntansi dan pemasaran serta pengendalian SDM sehingga mendatangkan manfaat bagi tim pengabdian dan juga masyarakat khususnya di wilayah Dusun Kulubanyu Desa Tawangrejo Kecamatan Jatirejo Kabupaten Mojokerto Provinsi Jawa Timur. 


\section{UCAPAN TERIMAKASIH}

Ucapan terima kasih kepada bapak Kepala Desa, Sekertaris Desa, dan Kepala Dusun serta kepala tim produksi yang merupakan Ibu-Ibu warga Dusun Kulubanyu yang telah memberikan perijinan waktu dan tempatnya selama melaksana kegiatan pengabdian dapat terlaksana dengan baik. Tidak lupa juga ucapan terima kasih kepada mahasiswa Universitas Negeri Surabaya Jurusan Akuntansi yang telah membantu program pengabdian desa iini.

\section{DAFTAR PUSTAKA}

Ahmad Farouk, M Yasin dkk, 2015, Anotasi Undang - Undang No.6 tahun 2014 tentang Desa, PATTIRO, Jakarta

Herawati, J., Sumartiah, S., Sari, P. P., \& Wulandari, D. (2020). Literasi Laporan Keuangan Ibu-Ibu Wirogunan Yogyakarta. Jurnal Kewirausahaan Dan Bisnis, 25(2), 119. https://doi.org/10.20961/jkb.v25i2.43597

Kotler, P., Kartajaya, H., \& Setiawan, I. (2019). Marketing 4.0 Bergerak dari Tradisional ke Digital. Jakarta : Gramedia Widiasarana Indonesia.

Mulyadi. (2012). Akuntansi Biaya (Edisi 5). Yogyakarta : Salemba Empat.

Rahayu, E. S., \& Laela, S. (2018). Pengaruh Minat Berwirausaha Dan Penggunaan Sosial Media Terhadap Kewirausahaan Mahasiswa. Jurnal Pengembangan Wiraswasta, 20(3), 203. https://doi.org/10.33370/jpw.v20i3.246

Sigalingging, E, T. (2020). Strategi Pemasaran Digital Terhadap Peningkatan Minat Beli Konsumen. Journal of Business Management Education (JBME), 5(2). https://doi.org/10.17509/jbme.v5i2.24806

Zubaedi. (2013). Pengembangan Masyarakat: Wacana \& Praktik. Jakarta : KENCANA. 